\title{
Agile Policy in the Application of Protection Policies and Fulfillment of the Rights of Persons with Disabilities in the Special Regions of Yogyakarta
}

\author{
Ernanda Pratama ${ }^{1}$, Dian Fadilah Rahmwati ${ }^{2}$, Arista Damayanti ${ }^{3}$, Kurnia Nur Fitriana ${ }^{4}$ \\ 1,2,3,4 Department of Public Administration, Yogyakarta State University, Indonesia \\ 1ernandapratama.2017@student.uny.ac.id,2dian1321fis@student.uny.ac.id, \\ 3aristadamayanti.2017@student.uny.ac.id, ${ }^{4}$ kurnianurfitriana@uny.ac.id
}

\begin{abstract}
The uurgency of this research is based on inclusive development efforts undertaken in the Special Region of Yogyakarta in the context of realizing contributions, opportunities and participatory space and respect for human rights values and principles reflected in policies for the protection and fulfillment of the rights of persons with disabilities in the perspective of Agile Policy. The research design used is a qualitative approach with the literary study method. From this background and identification of the problem, it can be seen that through the indicators from Arjun Bisen (2018), the point is: (1) Focus on customer over contract negotiations, (2) Prioritize working software before documentation, (3) Encourage individual interactions, not just process, (4) Plan for change instead of following a plan. Based on these points,
\end{abstract}

Keywords: Agile Policy, Policy, Disability, Special Region of Yogyakarta

\section{Introduction}

This study aims to determine the application of Agile Policy in policies to protect and fulfill the rights of persons with disabilities in the Special Region of Yogyakarta and how to achieve it. The research design used is a qualitative approach with literature study methods. The subjects in this study were all forms of policy content to fulfill the rights of persons with disabilities in the Special Region of Yogyakarta. Data collection techniques used are onlinebased browsing, physical studies of literature, photo documentation, pictures, graphs, tables, and related quantitative and qualitative data. The technique of testing the validity of the data used source triangulation. The data analysis technique used consists of three channels, namely data reduction, data presentation and drawing conclusions or verification.

\section{Literature Review}

Agile is a mindset and habit. The concept of agile policy is a concept developed from the concept of agile governance by Soe and Drechsler (2018: 324). The concept of agile governance was introduced by Wang, Medaglia, and Zheng (2018) as a type of adaptive governance. Governance can simply be understood as decision making and the exercise of authority to guide the behavior of both individuals and organizations. In governance there is usually the creation and enforcement of clear rules, less explicit social norms, guidelines, policies, or the creation of a defined command structure (WEF, 2018).

Agile governance according to Soe and Drechsler (2018: 324) is governance that is 
characterized by a fast and responsive process. Where this aims to change the way in which policies are made, discussed, enforced and enforced. This opinion suggests that the concept of agile is expected to be able to balance the rapid changes occurring in today's society, both governance in general and policies in particular. This agile concept is a user-centered design, cross-sector collaboration, rapid prototyping and iteration processes and continuous feedback (Bisen, 2018). Researchers use four indicators of agile principles that are applied in policy making proposed by Bisen (2018) to analyze policies to fulfill the rights of persons with disabilities in the Special Region of Yogyakarta, including:

a. Focus on policy users (Responsive)

Policy makers must be responsive and continuously build communication with the community in order to gain and maintain public trust. This can be done in a number of ways, such as hearings, public hearings or the opening of the media channeling aspirations. Responsiveness here refers to the government's ability to identify and make community needs and demands the basis for policy making and provision of public services (Dwiyanto, 2008: 62; Hobolt \& Klemmensen, 2008: 309). Furthermore, Zeithaml, et al. (in Hardiyansyah, 2011) states that responsiveness is a willingness to help consumers be responsible for the quality of services provided. Then, Santoso (2008) states that responsiveness is the ability of public institutions to respond to community needs.

b. Prioritizing policy products that are eligible for testing (Sustainability)

In this case, the policy product made must be in accordance with the experience and needs of the target group. The emergence of problems that will become an upstream policy must contain an element of attachment and interest with the target group so that later the existing policies are in line with the target group and are well implemented, so that the feedback that is expected to emerge from the implementation process can be an effort to improve in the future. Because the sustainability aspect can run with feedback from the target group. Whether it's positive feedback, negative feedback, zero feedback or neutral feedback (Rachmatie, 2002).

c. Encourage interaction between individuals (Dynamic)

The need for policies to deal with problems and needs in an era of change and uncertainty like today, makes policy makers must be able to see problems and needs from various perspectives. This then demands collaboration between actors and the interaction of all elements in policy making in order to create policies that are right on target. Dynamic in this case emphasizes policies, institutions and structures that are able to adapt to environmental conditions full of uncertainty and change so that the goals to be achieved can be realized effectively and efficiently (Neo and Chen, 2007). Then, this concept needs to be supported by a dynamic organizational culture and bureaucracy, with integrity, not corruption, and based on a merit system (work performance).

d. Sensitive to change (Adaptive)

Changes in individual behavior due to advances in communication technology make policy makers must be responsive and adaptive. As has been explained that public service providers need to think about the best way (innovation). Innovation can be realized with the ability to adapt to environmental conditions and changes. Adaptation to public service delivery can be realized through flexible means and policies. Adaptation is intended so that public service providers have a way of making quick and precise decisions in accordance with legal corridors in responding to environmental changes. 


\section{Results and Discussion}

\subsection{Policy for Fulfilling the Rights of Persons with Disabilities at Related Agencies}

Based on these four indicators, the researcher then analyzes the policies contained in private, community, government agencies and non-governmental organizations in the Yogyakarta Special Region to determine the extent to which the agile policy concept is applied.

\section{a. Private Institution \\ PT Jogja Tugu Trans}

As a business entity that provides public transportation services, based on research by Hiban, et al. (2020) PT Jogja Tugu Trans has participated in implementing government policies regarding the fulfillment of the rights of persons with disabilities for service users such as special facilities for the disabled on Trans Jogja, namely a bus stop equipped with stairs. sloping. This ladder is specifically intended for disabled people, especially wheelchair users. At some shelters, the Trans Jogja bus stop has been made sloping, however at some shelters, the floors at the bus stop are still quite steep, not wide enough and directly adjacent to buildings or trees so that it can be dangerous for disabled people.

Another thing is also stated in the research of Rahayu et al. (2013) that the service effort turns out that in practice it does not always provide convenience for diffables. Some things still pay less attention to the existence of people with disabilities as consumers. People with disabilities still experience difficulties in accessing city buses, especially for disabled wheelchair users. Some of the obstacles for diffables in using Transjogja are: 1 . There is too wide space between the bus stop and the bus that stops. This makes it difficult for people with disabilities, visually impaired, wheelchair users, and sufferers of semi-ambulants (walking disorders but without using a wheelchair) to get on or get out of the bus. 2. The ramp at the exit / entrance of the bus stop is too steep, almost up to 45 degrees. This will certainly make it difficult for people with disabilities in wheelchairs and for families who push the wheelchair. Whereas based on the standard of disabled facilities, the ideal ramp has a size of 1:12 to 1:15 between the height and base. 3. Existing ramps are often directly adjacent to flagpoles, parks, trees, and other objects without space for wheelchairs, making it difficult for people with disabilities to get on and off the bus stops. There is a fairly large difference in height between the road and the Trans Jogja bus stop without a limiting ramp. 4. The difference in height where the bus stops are generally $20-30 \mathrm{~cm}$ higher than the bus gate. This makes it difficult for people with disabilities to get out of the bus. 5 . The entrance to the bus stop is equipped with triangular bars that make it difficult for wheelchair users to access. 6 . The space inside the bus stop is not wide enough, making it difficult for wheelchair users to rotate. 7 . There are no clues / information / voice signals / alarms for the disabled and blind so that they get off the wrong path or take the wrong direction. Some of these things certainly indicate that the existing policies to fulfill the rights of disabilities can be said to have not met the agile policy indicators, considering that based on the points above, it does not reflect the optimal policies that focus on users, sustainability indicators, encouragement for interaction between individuals and adaptive to change. not seen yet.

\section{b. Public}

\section{Kebonagung Village Community}

Kebonagung Village in Bantul Regency succeeded in getting the title as the first Inclusive Disaster Resilient Village in the Yogyakarta Special Region Province thanks to the persistence 
of village leaders and organizations related to disaster management activities such as FPRB, $\mathrm{PB}$, and ASB. All community groups, especially vulnerable communities such as persons with disabilities, children, pregnant women, and the elderly are actively involved and voice their aspirations in the process towards an inclusive disaster resilient village. Apart from the roles of various parties, it turns out that the elements of local wisdom possessed by the people of Kebonagung Village also have an important effect on this success.

as well as sensitive and responsive plans for persons with disabilities to support resilience for groups of people with disabilities, d) strengthening evidence based on data and information on the situation of a person or group of persons with disabilities in planning and implementing disaster resilience strategies, e) increasing knowledge and awareness regarding beneficial disaster management for all. Disasters can occur at any time beyond human prediction. Based on this description, we can all know that the agile policy indicator in the effort to fulfill the rights of disabilities in Kebonagung Village, Imogiri District, Bantul Regency in the Inclusive Disaster Tangguh Village policy can already be seen well. Starting from community involvement, sustainability, involving various actors to being sensitive to change. d) strengthening evidence based on data and information on the situation of a person or group of persons with disabilities in planning and implementing disaster resilience strategies, e) increasing knowledge and awareness regarding disaster management that benefits all. Disasters can occur at any time beyond human prediction. Based on this description, we can know together that the agile policy indicator in the effort to fulfill the rights of disabilities in Kebonagung Village, Imogiri District, Bantul Regency in the Inclusive Disaster Tangguh Village policy can be seen well. Starting from community involvement, sustainability, involving various actors to being sensitive to change. d) strengthening evidence based on data and information on the situation of a person or group of persons with disabilities in planning and implementing disaster resilience strategies, e) increasing knowledge and awareness regarding disaster management that is beneficial for all. Disasters can occur at any time beyond human prediction. Based on this description, we can know together that the agile policy indicator in the effort to fulfill the rights of disabilities in Kebonagung Village, Imogiri District, Bantul Regency in the Inclusive Disaster Tangguh Village policy can already be seen well. Starting from community involvement, sustainability, involving various actors to being sensitive to change. Disasters can occur at any time beyond human prediction. Based on this description, we can know together that the agile policy indicator in the effort to fulfill the rights of disabilities in Kebonagung Village, Imogiri District, Bantul Regency in the Inclusive Disaster Tangguh Village policy can be seen well. Starting from community involvement, sustainability, involving various actors to being sensitive to change. Disasters can occur at any time beyond human prediction. Based on this description, we can know together that the agile policy indicator in the effort to fulfill the rights of disabilities in Kebonagung Village, Imogiri District, Bantul Regency in the Inclusive Disaster Tangguh Village policy can already be seen well. Starting from community involvement, sustainability, involving various actors to being sensitive to change.

c. Government agencies

1. Social Service of Yogyakarta Special Province

The Yogyakarta Special Region Social Service has the task of dealing with social problems in the DIY province with the help of partners. One of the DIY Social Service partners is the Integrated Rehabilitation Center for Persons with Disabilities (BRTPD) located in Bantul Regency. Balai BRTPD as a place of rehabilitation and an institution that provides job skills training for persons with disabilities in accordance with market needs. This is one of 
the implementations of law number 8 of 2016 regarding the number of disabled workers in a company.

The training provided is tailored to market demands such as sewing, reflexology, graphic design, computer skills, leather skills, silver skills and electronics skills. The purpose of this guidance is to prepare people with disabilities to work in a company. The type of training is adjusted to the conditions of persons with disabilities, so that in carrying it out it is not an obstacle, before determining the type of training that persons with disabilities will receive tests to determine their interests and talents.

\section{DIY Department of Manpower and Transmigration}

The Department of Manpower and Transmigration or Disnakertrans of the Special Region of Yogyakarta is in charge of carrying out government affairs in the labor sector and government affairs in the field of transmigration. The DIY Manpower and Transmigration Office has a mission to improve the quality of life and life of a just and civilized society. The goal is to improve the quality of life and community livelihoods with a social order that ensures diversity and is able to maintain and develop Yogyakarta culture. The program initiated by the DIY Disnakertrasn is to hold a job fair by providing vacancies for people with disabilities. This program supports the law regarding the quota for workers with disabilities in companies so that the implementation of this program is a form of government response in supporting the fulfillment of the rights of persons with disabilities.

\section{DIY Health Office}

The DIY Provincial Government through the DIY Health Office provides assistance in the form of health aids as regulated in Pergub No. 83/2014 regarding assistance aids for disabled Jamkesus participants. The goal is to make it easier for persons with disabilities to carry out their daily activities. The regulation regarding the provision of medical aid for persons with disabilities in the DIY province is a form of response from the government towards fulfilling the rights of persons with disabilities. This is related to the level of economic ability of persons with disabilities, not all of them come from an established family. The government is here to fulfill the rights of persons with disabilities. This is a form of government response through the DIY Health Office in an effort to fulfill the rights of persons with disabilities.

A. Non Governmental Institution

1) PATTIRO

PATTIRO (Regional Center for Research and Information) is a research and advocacy organization that focuses on issues of local governance, especially on issues of decentralization. In its work program PATTIRO encourages the creation of good, transparent and fair local government governance to create social welfare for the people of Indonesia.

One of PATTIRO's programs is to form a community of people with disabilities, including the Disability Potential Development Center (P3D) and the Mobile Disability Group (KDLB). So that through the P3D and KDLB communities, PATTIRO tries to encourage the participation of citizens with disabilities as an effort to fulfill the rights of persons with disabilities to live properly. In program implementation, persons with disabilities participate in almost all innovation processes, starting from the planning, implementation, to follow-up and advocacy stages, and coordination with the Social Service, Health Office and Puskesmas through training on how to communicate and interact with people with disabilities (http://pattiro.org). 
In the implementation of the program, PATTIRO has developed a public complaint handling model, a social integrity and accountability audit model, and a transparency intervention model for public service accountability, publishing a number of publications, such as books, training modules, policy briefs and lesson learned documents to disseminate activity results. This publication is intended so that the results obtained can reach a wider audience and motivate interested parties to replicate similar activities / programs. Apart from the mass media, publications are also disseminated through the websitewww.pattiro.org.

2) SIGAB

The Target of Integration and Advocacy for Difabel (SIGAB) is a nongovernmental organization that is engaged in defending and fighting for the rights of disabilities to create an inclusive and equal life for people with disabilities throughout Indonesia. In one of the SIGAB programs, one of them is the Phase 1 Disability Pillar Care Program, which is a program that facilitates the development of innovations and good practices. community support from the program. One of the implementation of the program in Yogyakarta is in Bumijo Village, where SIGAB, Puskesmas, and the village government work together in dealing with People with Mental Disorders (OGDJ).

The following activities in this program are: 1) Routine examination as a pre-incentive measure as well as early detection of ODGJ recurrence; 2) Budget allocation for referrals, training for puskesmas officers in providing quick responses and services for ODGJ; 3) ODGJ Prevention Forum; 4) Campaign at the village level in the form of multi-stakeholder forums at the village level; 5) Job training and inclusion of working capital or production tools for ODGJ who recover and ODGJ families to strengthen their economic conditions; 6) Provision of Special Health Insurance for ODGJ (integrated withJKN); and 7) ODGJ Family Support Forum.

\section{3) YAKKUM}

YAKKUM is a non-governmental organization engaged in the rehabilitation of persons with disabilities to fulfill their basic rights and empower them. Programs carried out by this institution are: 1) Disabled Person Organization (DPO), to support persons with disabilities to work or become entrepreneurs; 2) Community-based mental health program, to increase community awareness of ODG and improve the quality of life of ODG; 3) Prosthetics and orthodics, to produce prosthetic and orthotic aids which aim to increase mobility and facilitate activities for persons with disabilities; 4) Job Training, to offer skills training such as sewing, servicing, and batik; 5) Education, to prepare children with cerebral palsy before entering primary education both in formal schools and in special schools.

With the theme of empowering youth with disabilities, the YAKKUM Rehabilitation Center provides skills that are different from empowering with disabilities in general. Namely barista training in the coffee sector with the hope that young people with disabilities can work in a field that is on the rise according to the current passion and development. As stated by $\mathrm{AD}$, the implementation of this strategy is carried out by approaching all levels of society and by campaigning on issues. -Disability issues (Fatmaningsih, 2020). 


\subsection{Agile Policy Implementation in Agency Policy}

To find out the implementation of agile policy on policies to fulfill the rights of persons with disabilities, it can be analyzed based on four indicators of implementing agile policy according to Arjun Bisen (2018):

1. Focus on customers rather than contract negotiations

Based on how many non-governmental organizations that focus on empowering and expanding job opportunities for persons with disabilities are Sanggar Saujana and Yayasan Yakkum and which focus on advocacy processes and services. Sanggar Saujana implements the MKPD Disability Partner Program, but in several evaluation results, the implementation of job training programs is still not optimal. This is due to the absence of a match between the types of job needs and the abilities of persons with disabilities, as well as the lack of innovative types of training available, so that it can reduce the interest of persons with disabilities, and is less relevant to the needs of job vacancies for people with disabilities who currently switch to administration, and editor.

2. Prioritize functional software before documentation

Websites and mobile software-based information systems that serve as media in accessing data, and assisting in the management of disability services from several non-governmental organizations such as PATTIRO, SIGAB, and YAKUM in DIY are still limited. One of the websites and mobile software information systems from the YAKUM institution which is a medium of liaison between persons with disabilities, job seekers and job providers called Kerjaabilitas.com. In addition, there is the development of a sign language system application and integrated disability services starting in 2015 as an effort to support the disability equalization policy. However, there are no other application and software services to optimize the equality policy for persons with disabilities through an agile policy.

3. Encourage individual interaction, not just processes

Non-governmental organizations through PATTIRO, SIGAB, and YAKUB have made efforts to encourage interaction through communication in an effort to convey policies to the parties involved, both teams from these institutions, related agencies, and the community. At the PATTIRO institution, communication is carried out by forming a community of people with disabilities, including the Disability Potential Development Center (P3D) and the Lingsar Mobile Disability Group (KDLB). So that through the P3D and KDLB communities, PATTIRO tries to encourage the participation of citizens with disabilities as an effort to fulfill the rights of persons with disabilities to live properly.

In program implementation, persons with disabilities participate in almost all innovation processes, from the planning, implementation, to follow-up and advocacy stages, and coordination with the Social Service, Health Office and Puskesmas through training on how to communicate and interact with people with disabilities. In addition, PATTIRO also provides a forum for public complaints as a form of public service for several related agencies in supporting the fulfillment of disability rights.

In addition to the PATTIRO institution, the SIGAB organization also conducts a program related to the Training of Mental Health Cadres by involving the village government, residents, and community leaders. This 
program is one of the communication media for the SIGAB institution in its efforts to deal with Insider Mental Disorders. In this program there are also Campaign activities at the village level in the form of multi-stakeholder forums at the village level.

4. Plan for change instead of following a plan

In a non-governmental organization, in carrying out policy reforms according to the needs of problems that focus on institutional goals with policies that lead to change, then design plans and policies that expect change as a solution, especially in policies to fulfill disability rights. Therefore, a rapid feedback economy to better understand the changes that are taking place is very important for PATTIRO, SIGAB, and YAKKUM in the fulfillment of disability rights. However, until now, researchers have not found a real effort through the programs or activities of these institutions as a step to address growing problems as needed. This is a driving factor for non-government organizations to continue to innovate.

\section{Conclusion}

a) Supporting factors

There are several supporting factors for the implementation of programs and activities carried out by non-governmental organizations, namely PATTIRO, SIGAB, and YAKKUM in implementing policies to fulfill disability rights. Where these institutions have provided a platform for efforts to develop and fulfill the rights of persons with disabilities through various programs carried out by the PATTIRO, SIGAB and YAKKUM institutions in collaboration with various agencies, such as local governments, communities and the private sector. Participatory efforts made by institutions are an opportunity to help the program succeed, both with the assistance of services and budgets from related agencies.

b) Obstacle factor

In the programs and activities carried out by non-governmental organizations, namely PATTIRO, SIGAB, and YAKKUM, there are still many agile policy indicators that do not meet the indicators. This is because there is still no innovation in program implementation or the media in assisting program implementation. In addition, the problems are increasingly developing, in accordance with the times through the development of technology and information systems that are still minimal so that they are not optimal in becoming a forum for persons with disabilities to develop their potential and fulfill their rights.

\section{acknowledgment}

Praise the presence of Allah SWT for giving His grace and guidance in the form of opportunity, health, convenience, and smoothness so that the author can complete the final report entitled "Agile Policy in the Application of Protection Policies and Fulfillment of the Rights of Persons with Disabilities in the Special Regions of Yogyakarta "well.

Help and support from all parties really helped the author in completing this 
journal. Allow the author to thank all those who have supported and helped the author to complete this journal. On this occasion, thanks are conveyed to Kurnia Nur Fitriana, MPA as the supervisor who always provides knowledge and guidance until the completion of this final report.

Hopefully this final report will be of use to all of us. Thank you for the assistance in the form of knowledge, support and material from all parties so that this final report can be completed.

\section{References}

[1] Agustino, L. (2006). Basics of Public Policy: Bandung: AIPI Bandung-Puslit KP2W Lemlit Unpad 2006b. Politics and Public Policy.

[2] Akbar, RI (2013). Comparison Between Agile Methodology And Plan Driven AS Method For Erp Development. Sisfotenika, 3 (1), 11-20.

[3] Coal, AH (2011). Public Service as an Entrance in Realizing Good Governance.

[4] Cochran, CE, Mayer, LC, Carr, TR, Cayer, NJ, \& McKenzie, M. (2015). American public policy: An introduction. Nelson Education.

[5] Cook Curtins, W., \& Philip, H. (2007). Management and organizational behavior.

[6] Dewi, U. (2015). Implementation of the Quota policy for Persons with Disabilities to Get a Job in the city of Yogyakarta. Natapraja Journal: State Administration Studies, 3 (2).

[7] Dewi, U., Harith, NHM, Harsono, D., Ali, AJM, \& Fitriana, KN (2020, February). Employment Governance for People with Disabilities: Comparative Study Between Indonesia and Malaysia. In International Conference on Educational Research and Innovation (ICERI 2019) (pp. 232238). Atlantis Press.

[8] Dewi, U., Yuanjaya, P., Kuncorowati, PW, \& Fitriana, KN (2020, February). Elderly Healthy Home for Promoting Inclusive Health Services in Indonesia. In International Conference on Educational Research and Innovation (ICERI 2019) (pp. 259-264). Atlantis Press.

[9] Fatmaningsih, Adhisty. (2020). Public Relations Strategy by the YAKKUM Rehabilitation Center at the Cupable Coffee Shop Yogyakarta in Forming an Image of "Disability Friendly Cafe". Commercium. Volume 02 Number 02 Year 2020, 88 - 89. Accessed from:https://core.ac.uk/download/pdf/286131974.pdf

[10] Hardiyansyah, H. (2018). Quality of Public Services: Concept, Dimensions, Indicators and Implementation. Gava Media.

[11] Harimisa, D. (2017). Criminal Actions Obstruct or Prohibit the Rights of Persons with Disabilities According to Article 145 of Law Number 8 of 2016 concerning Persons with Disabilities. Lex Privatum, 5 (5).

[12] Hermawan, W. (1995). Introduction to Research Methodology. Jakarta: Gramedia Pustaka Utaama.

[13] Hiban, MI, Purnomo, EP, \& Nurkasiwi, A. (2020). Smart City in Fulfilling the Rights of Persons with Disabilities in Yogyakarta "Case Study: Public Transportation Infrastructure in Fulfilling the Rights of Persons with Disabilities". Journal of Government and Politics, 5 (2).

[14] Hobolt, SB, \& Klemmensen, R. (2008). Government Responsiveness in Word and Actions: Policy Promises and Public Spending in Comparative Perspective. Comparative Political Studies.

[15] Indonesia, DPRR (1997). Law of the Republic of Indonesia Number 4 of 1997 concerning Persons with Disabilities.

[16] Indonesia, KBB (2008). Language Center (Fourth Edition) Ministry of National Education. Jakarta: PT Gramedia Pustaka Utama.

[17] Indonesia, PR (1997). Law No. 4 of 1997 on Persons with Disabilities. State Gazette of the Republic of Indonesia Year, (9).

[18] Indonesia, R. (2012). Yogyakarta Special Region Provincial Regulation No. 4 of 2012 concerning Protection and Fulfillment of the Rights of Persons with Disabilities. Yogyakarta 
Special Region Provincial Gazette Year.

[19] Indonesia, R. (2012). Yogyakarta Special Region Provincial Regulation No. 4 of 2012 concerning Protection and Fulfillment of the Rights of Persons with Disabilities. Yogyakarta Special Region Provincial Gazette Year.

[20] Windows, B. Health information. 2014. Situation of Persons with Disabilities. Semester II. RI Ministry of Health. ISSN data.

[21] Kansil, CST (1989). Introduction to Indonesian Law and Legal Administration, Cet. 7th. Jakarta: Balai Pustaka.

[22] Ministry of Health, RI (2014). Bulletin Data and Health Information Window on the Situation of Persons with Disabilities.

[23] Krispendoff, K. (1993). Introductory Content Analysis and Theory Methodology. Jakarta (ID).

[24] Moleong Lexy, J. (2011). Qualitative Research Methods, (Bandung: Youth Rosdakarya, 2001), Cet. 1 M. Suqi Amin and Hasan Ali Utbah, Al-Mu'jam Al Wasit, Juz I, (Cairo: Darul Kutub, 1982). Narwani Sri.

[25] Neo, BS, \& Chen, G. (2007). Dynamic governance: Embedding culture, capabilities and change in Singapore (English version). World Scientific.

[26] Number, UU (19). year 2011 regarding ratification. In Convention on the Rights of Persons with Disabilities.

[27] Number, UU (39). 1999 concerning Human Rights.

[28] Novita Anggraeni, \& Utomo, Sad Dian. 2018.Public Services for Disabilities Review of Good Practices and Innovations from Partners of the Phase 1 Disability Pillar Care Program (20152016) in Five Provinces in the Public Service Sector.

[29] Pawestri, A. (2017). Rights of Persons with Disabilities in International and National Human Rights Perspective. Era of Law-Scientific Journal of Law, 15 (1).

[30] DIY Governor Regulation. (2013). Yogyakarta Special Region Governor Regulation Number 41 of 2013 concerning the Center for Inclusive Education Resources.

[31] DIY Governor Regulation. (2013). Yogyakarta Special Region Governor Regulation Number 31 of 2013 concerning the Committee for the Protection and Fulfillment of the Rights of Persons with Disabilities.

[32] DIY Governor Regulation. (2013). Yogyakarta Special Region Governor Regulation Number 51 of 2013 concerning the System for Administering Special Health Insurance for Persons with Disabilities.

[33] DIY Governor Regulation. (2014). Yogyakarta Special Region Governor Regulation Number 64 of 2014 concerning Protection and Participation of Persons with Disabilities in Disaster Management.

[34] DIY Governor Regulation. (2014). Yogyakarta Special Region Governor Regulation Number 61 of 2014 concerning Economic Business Development for Persons with Disabilities.

[35] DIY Governor Regulation. (2014). Yogyakarta Special Region Governor Regulation Number 60 of 2014 concerning Procedures for Providing Legal Aid for Persons with Disabilities.

[36] DIY Governor Regulation. (2014). Yogyakarta Special Region Governor Regulation Number 14 of 2014 concerning Needs Assessment of Persons with Disabilities.

[37] DIY Governor Regulation. (2014). Yogyakarta Special Region Governor Regulation Number 83 of 2014 concerning Assistance for Health Assistance Devices for Participants of Special Health Insurance for Persons with Disabilities.

[38] DIY Governor Regulation. (2018). Yogyakarta Special Region Governor Regulation Number 90 of 2018 concerning the Formation, Organizational Structure, Duties, Functions and Work Procedures of Technical Implementing Units at the Social Service.

[39] DIY Governor Regulation. (2018). Yogyakarta Special Region Governor Regulation Number 69 of 2018 concerning Position, Organizational Structure, Duties, Functions and Work Procedures of the Health Service.

[40] Purwanto, Erwan Agus. (2019). Agile and Innovative Public Policies Winning Competition in the Vuca Era (Volatile, Uncertain, Complex and Ambiguous). Inauguration Speech for Professor of Public Policy at the Faculty of Social and Political Sciences, Gadjah Mada University. 
[41] Rahayu, S., \& Dewi, U. (2013). Public Services for Fulfilling the Rights of Disabilities in Yogyakarta City. Natapraja Journal: State Administration Studies, 1 (1).

[42] Reefani, NK (2013). Guide for Children with Special Needs. Yogyakarta: Imperium.

[43] Rompis, KG (2016). Legal Protection of Persons with Disabilities in the Perspective of Human Rights Law. Lex Administratum, 4 (2).

[44] Santosa, P. (2009). Public Administration: Theory and Application of Good Governance. Refika Aditama.

[45] Sugi Rahayu, UD, \& Ahdiyana, M. (2013). Public Services in the Field of Transportation for Disabilities in the Special Region of Yogyakarta. SOCIA: Journal of the Social Sciences, 10 (2).

[46] Suminar, RE, \& Pranindita, N. Local Community Wisdom in Progress Towards an Inclusive Disaster Resilient Village: A Lesson from the Community of Kebonagung Bantul, Yogyakarta.

[47] Suprayogo, I., \& Tobroni. (2001). Social-Religious Research Methodology. Rosdakarya youth.

[48] Law, RI (1997). Law of the Republic of Indonesia Number 4 of 1997 concerning Persons with Disabilities.

[49] Law, RI (2016). Law of the Republic of Indonesia Number 8 of 2016 concerning Persons with Disabilities.

[50] Law, RI (2016). Law of the Republic of Indonesia Number 8 of 2016 concerning Persons with Disabilities.

[51] Winarno, B. (2007). Public policy: Theory and process. Yogyakarta: Media Pressindo.

[52] Zakiyah, U., Husein, R., \& Muzwardi, A. (2013). Inclusive Services for Persons with Disabilities Study of Tourism Facilities and Accessibility for Disabilities in Yogyakarta City. World Health, 169. 